Sultan Qaboos University Journal of Arts \& Social Sciences

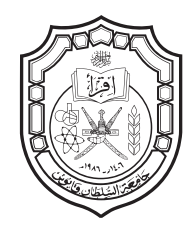

جامعة السلطان قابوس مجلة الآداب والعلوم الاجتماعية

\title{
The Nature of Oman's Relations with Iran
}

\section{Dr. Hani Albasoos}

Department of Political Science, College of Economics \& Political Science

Sultan Qaboos University, hani.adam@squ.edu.om

\author{
Zeinab Mohammed Ali \\ Research Assistant, \\ Department of Political Science, \\ College of Economics \& Political \\ Science \\ Sultan Qaboos University,
} Zainabmohammed38@gmail.com

\begin{tabular}{c}
\hline Sara Al Shizawi \\
\hline An independent researcher in \\
Omani Politics
\end{tabular}

Sshizawi@gmail.com

\footnotetext{
Asila S. Al Hasni

An independent researcher in Omani Politics asilaalhasni@gmail.com
} 


\title{
The Nature of Oman's Relations with Iran
}

\author{
Albasoos, Ali, Al Hasni, Al Shizawi
}

Abstract:

Relations between the Sultanate of Oman and the Islamic Republic of Iran extend back to the ancient civilisations that inhabited both regions. At first, trade was the only connection between the two countries. This later evolved into the Persian occupation of Oman which ended in the first century BC after the battle of Saloot. However, these ancient relations are irrelevant to this paper which seeks to examine the nature of the relations between the two states in current times. Oman recognizes Iran as an ancient civilization, not just a new or modernized state. Oman does not ignore the role of Iran in the region and gives it its deserved attention. This is because Oman understands Iran's significant contemporary and historical position in the Middle East.It is undoubted that Omani influence reached the Iranian territories through the message of Islam. This was the result of Omani merchants and travelers who sailed through the golden strait(Hormuz) to the Iranian border. Moreover, some Persian and Arab tribes settled in the north cost of Oman and lived peacefully together till the modern days. Oman-Iran's relationship is based on reciprocal respect and not interfering in the internal affairs of both states. The security and logistic cooperation between the two states was very strong in the 1970s and reached its peak in 1977, when the Shah of Iran visited Oman. In the 1970s, Oman signed several agreements, many of which were with Iran, to secure itself from communist threats.

Keywords: Oman, Iran, Relations, the Gulf, GCC

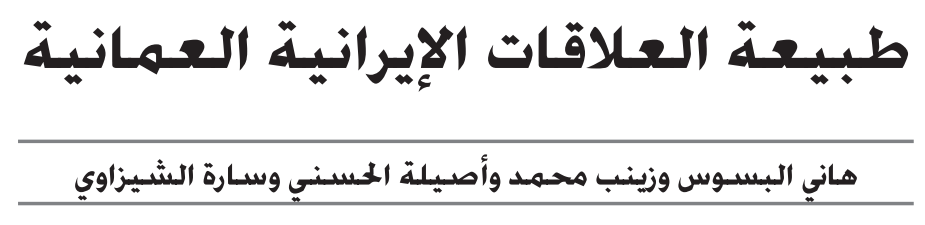

المللخهص:

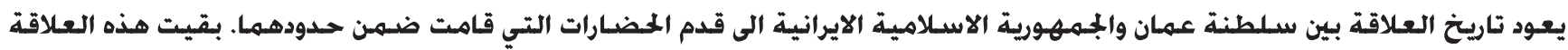

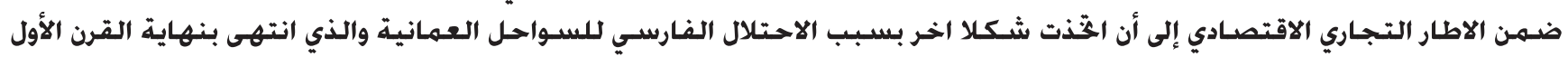

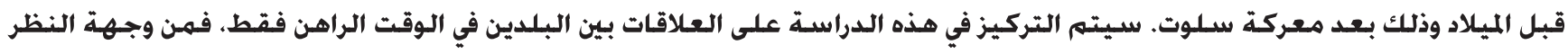

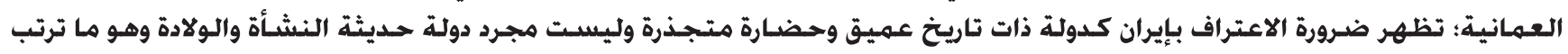

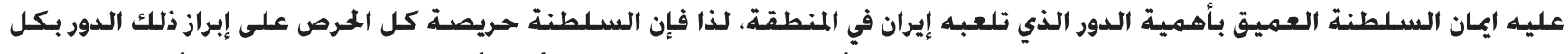

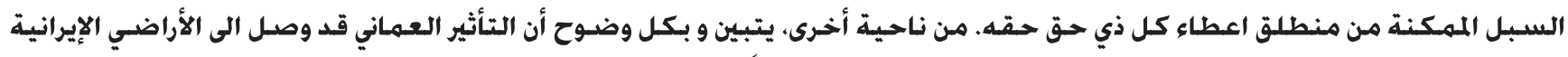

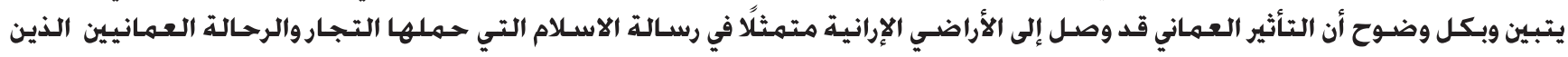

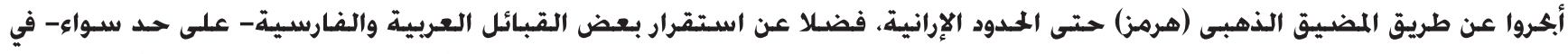

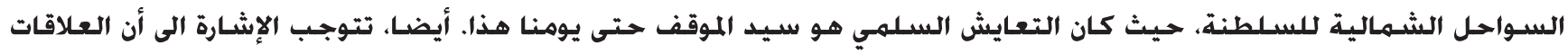

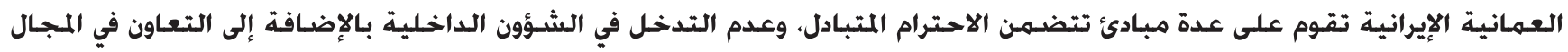

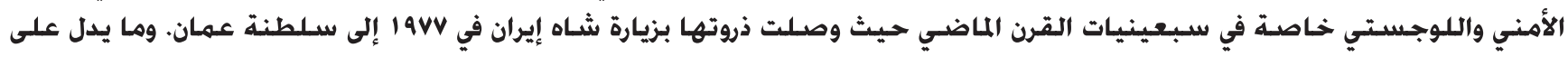

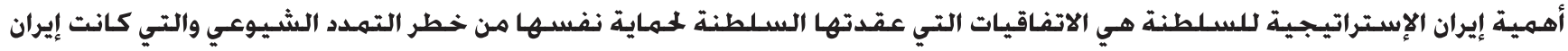
طرفا في كثير منها. 
Introduction:

In this research paper, we will first briefly examine the nature of Omani policy and its main characteristics. We will then provide a brief look into the relations between Oman and Iran from 1970 till modern times. This part will be divided into two: the relations between the two countries during the time of the Shah and the Islamic revolution in 1979. Then, we will look into the current political relations between the two states, talking about them broadly at first, and then focusing on a few key events that tested this relation. We will then explore the importance of the Strait of Hormuz to the international arena and its role in strengthening the ties between the two countries. The final section will examine the economic and social relations between the two states.

\section{Oman's Foreign Policy:}

The best expression to be used to describe the Omani foreign policy is unique, seeing that it differs from the policies of Oman's neighbours and partners in the Gulf Cooperation Council (GCC). Since the beginning of his rule, His Majesty Sultan Qaboos has remarkably increased Oman's presence and activity in the international community, thus ending the isolation of Oman's foreign policy. This is evident in Oman's joining of the United Nations and the Arab League in 1971, just one year after His Majesty's accession to the throne.

The Sultanate of Oman relies on a set of principles in formulating its foreign policy and conducting any activity abroad. These characteristics have existed since the beginning of Sultan Qaboos' reign and are likely to continue in the future. The first principle is not to interfere in the internal affairs of other states. This means that Oman refuses to go into another state and meddle with its affairs. If a country is suffering from any internal issues or conflicts, then its government has the duty to resolve them. This is why Oman refrains from undermining other states' sovereignties. This has helped preserve good relations between Oman and other states, and foster peace and unity in the region.

The second principle of Omani foreign policy is the rejection of cutting diplomatic and political ties with other countries. This was clear after the Camp David Accord between Egypt and Israel in 1978, where Oman refused to cut diplomatic relations with Egypt, despite that most Arab countries severed their relations with Egypt. This policy was also evident during the Iraqi invasion of Kuwait, where Oman did not cut ties with Iraq in spite of the fact that the other GCC countries discontinued their ties with Iraq. The same rule applies to Syria and Yemen in current times.
Oman believes that conflicts are best resolved via conversation, not through fighting or declaring wars. Cutting off diplomatic ties stops conversations from happening, thus furthering the conflict and halting any efforts to reach peaceful solutions.

The third principle of Omani foreign policy is the rejection of forming and joining any axes or alliances that aim to attack another state, interfere in its domestic issues or participate in an international conflict. Oman believes that conflict and wars need to be prevented and resolved diplomatically; hence, it follows positive neutrality to gain the acceptance and confidence of the warring parties, which helps to get them sit together for dialogue and negotiations (Lefebvre, 2010).

Oman's policies are focused on political independence and the independence of thought, independence based on pragmatic planning and diplomatic endeavours, and is derived from Oman's rich history, geographic location, religion and leadership.

\section{An Overview of Omani-Iranian Relations:}

Throughout history, the relation between Oman and Iran fluctuated from peaceful neighbours to enemies at war and from cooperation to clashinges. The geographical dimension forced the two parties through history to interact due to the close vicinity and their shared maritime borders. The relation between the two states has been based on affinity and intermixing of tribes and ethnicities. The shared Islamic values of brotherhood and respect between Muslims has increased the cooperation between the two countries (Abu-zaid, 2010).

The GCC states are very strategically and logistically important to Iran due to the long Iranian coastline with $1200 \mathrm{KM}$ overlooking the Arabian Gulf from the north. Iran shares this gulf with Oman, the United Arab Emirates, Bahrain, Qatar and Kuwait. This coastline is considered to Iran's window to the world. Moreover, the Iranian oil industry, oil reserves and export ports are located near the Gulf states.

Oman's policy of maintaining relations with states, and not political systems, is evident in its relation with Iran. Oman realises the vital role Iran plays in the region and its effect on regional politics and stability. The Omani government has endeavored to reconcile relations between other GCC states and Iran as it believes that the Middle East security and stability is based on cooperation and open channels of communication between the Middle East countries and Iran (Al-Rawas: 134).

In the past, the Omani government had good relationships with the Shah, even though the period was short- only 9 years. Sultan Qaboos and the 
Shah encouraged security and political cooperation between the two states. The Shah was the mediator of the British in the Arabian Peninsula, and he acted as a shield to secure the region from all external and internal threats, a role that was possible for him to play considering that he had sufficient financial, diplomatic and military resources. This explains the assistance which the Shah provided to Oman in its fight against communism in Dhofar. The Soviets backing of nationalistic communism was a major threat to both Oman and Iran in the cold war era, and the Dhofar region in the Southern region of Oman was a battlefield for the Sultan's forces and the Dhofar Liberation Front, which was supported by the Soviet Union.

Bahlawi, the last Shah of Iran, supported Sultan Qaboos with 4000 soldiers and provided Oman with logistical support. His Majesty Sultan Qaboos said in an interview with Lebanese magazine AlHawadth that Iran defended itself in Dhofar as much as it defended Oman. The Omani government accepted this support, not only because Iran is a fellow Islamic state, but also because Iran and Oman considered that stopping the communist tide was a very important strategic move to maintain the security of the gulf. The cooperation between Iran and Oman was based on realizing the shared responsibility of securing the region. This demonstrates that Oman is very important logistically to Iran. Moreover, Bahlawi said in a meeting with Mohammed Haykel that Oman was very close to Iran and that anything that happened to Oman would affect Iran directly. Oman controls part of Hormuz and instability in Oman may impact the strait, which is very important for the Iranian government (Al-Rawas: 136).

Sultan Qaboos tried to create a powerful unity in cooperation with all parties in the region. Oman called for holding a political forum to increase security cooperation between Iran and the Arab Middle East countries; however, there wasn't any response from Saudi Arabia and Iraq, as they were both hesitant to strengthen relations with Iran. This hesitation could be based on their fear of Iran or their mistrust of it.

In addition to that, His Majesty visited Iran during the Shah period to participate in Iran's celebration of the passing of 2500 year for the Persian Empire in 1974, a visit which established the principles of security cooperation in the Strait of Hormuz. The 1974 visit ended by declaring that the two sides are responsible for maintaining the security of the Strait and that both states had to respect the other state's interest when implementing new strategies and had to maintain the free movement of ships in the Strait. In addition to that, Oman and Iran also reached an agreement in
1974 regarding the maritime borders between the two states. This was coupled with an agreement regarding the system of the naval police force patrolling the borders, stopping illegal movement and securing the Strait (Al-Rawas: 137).

\section{Relations After the Islamic Revolution:}

After the 1979 Iranian revolution, the Iranian government and the entire political system changed from a kingdom to an Islamic state. It was the first successful Islamic revolution in modern history. It created a huge shift in Iran's internal political system, which directly impacted its foreign policy. Iran changed its allies, partners and enemies. Iran has refused to play the role of Gulf "policeman: All states in the Middle East have to be responsible for regional security. It has also refused all security plans excluding it (Abu-zaid, 2010: 81).

These Iranian policy changes, both domestic and foreign, forced all countries to change their policy towards the Khomeini government, to be more suitable to the new government. Iran has even tried to export its Islamic revolution to all of the Gulf states to end the "monarchic dictatorship regimes". This has created some tension between Oman and Iran, especially after the emergence of some friction between the two countries in Hormuz. Therefore, Oman has tried to establish good relationships to secure its interest, so these frictions will not significantly influence Omani foreign policy (Al-Rawas: 136).

In 1979, Yosef Bin Alawi, Oman's Minister of Foreign Affairs, visited Iran, making him the second Arab political figure to visit Iran after the Islamic revolution. The two parties succeeded in refreshing the relations in a way that secured their mutual national interests. Oman, as a Gulf state, maintained its good relations with Iran. It might be considered the best relation with Iran for any country in the region. This is what makes Oman a mediator between other Gulf states and Iran, and sometime between other states and Iran (Al-Rawas: 136). Moreover, in the Iran- Iraq war and following the deterioration of Iran's relations with world biggest powers, Oman still kept its good relationship with the Khomeini government. Oman trusted Iran's ability to create a stable relationship with all governments in the Gulf. The minister of Oman's foreign affairs clarified on different occasions that Oman does not consider Iran a threat and that it sees it as a Gulf neighbour worthy of cooperation. Oman and Iran's relationship increased following several visits by important political personalities between the two states. Mohammed Khatami visited Oman in 2004 and Ahmadi Najad in 2007. Oman has always confirmed the importance of the participation 
of all states in the Gulf in any plan or discussion about issues concerning the Gulf region. Oman refused to attend a regional meeting in 2008 with the US, Germany, the GCC states, Iraq, Jordan, and Egypt because Iran and Pakistan were not invited.

Sultan Qaboos visited Iran in 2009 to improve economic cooperation and to export gas from Iran. This ended by signing an agreement between the two countries. Furthermore, Sultan Qaboos visited Iran in 2013 to reaffirm cooperation and friendship between the two states (Al-Rawas: 139).

\section{Current Relations:}

This history between Oman and Iran, a history of cooperation and non-conflict, has affected the current political/diplomatic relations between the two states. According to Sara Bazoobandi, an Iranian specialist at the UK Chatham House: "It's quite important for the Iranians to at least have one friend in the Gulf... Now that the situation is getting worse with the other GCC states, Tehran is more likely to put more effort into maintaining a better relationship with Oman" (Bazoobandi, 2015). One of many facts that prove that Oman is this "friend" is that Sultan Qaboos bin Said was the first head of state to meet the current Iranian president Hassan Rouhani in August 2013 (Torbati, 2013). Oman has also played the role of diplomatic representative for the UK in Iran since 2011, when the British embassy in Tehran was stormed by protesters (BBC, 2015). However, perhaps the most obvious example would be Omani diplomatic efforts in what is now known as the P1+5 talks with Iran about its nuclear power.

In July 2006, the UN issued Resolution 1696, the first in a series of resolutions that demanded Iran that cease its uranium enrichment activities (UN Security Council, 2006). The main players who voiced their demands were the five permanent members of the United Nations Security Council: the US, the UK, France, China and Russia. In addition to these countries, Germany was also a key player, being one of Iran's largest trading partners. Iran continued its uranium enrichment activities claiming that the uranium would only be used to generate clean energy. This led to severe sanctions imposed on Iran in the shape of limited trade, severed diplomatic relations and frozen assets. Negotiations between the P5+1 states and Iran began in February 2013 in Kazakhstan, where an interim agreement was reached. However, negotiations continued till the 14th of July 2015, when the Joint Comprehensive Plan of Action between the five permanent members of the UN Security Council, Germany and the EU was reached (BBC, 2016).

Oman's role in this plan was discreet as the Omani diplomacy is characterized by its lack of publicized efforts. Oman's role was vital in facilitating communications between the two parties, Iran and the $P 5+1$, and in ensuring that both sides understood where the other player stood. Oman was the advocate on behalf of Iran, explaining Iran's mistrust of the West, which was the cause of their lack of cooperation. Oman understood that the Iranian government did not trust the US after it toppled Saddam Hussein's government in Iraq in 2003, and had invaded Afghanistan. Omani diplomats understood the depth of Iranian mistrust. The American president George W. Bush did call Iran a member of the so called "Axis of Evil". Moreover, the Omanis reminded the P $5+1$ that Iran actually signed the Nuclear Non-Proliferation Treaty. The NPT bans all signatories from seeking or producing nuclear weapons. However, it does not ban them from harnessing nuclear energy to generate power for any other peaceful purpose.

Oman's relationship with Iran has enabled it to thoroughly understand the reason for the Iranian reluctance to cease nuclear activities. Iran claims that uranium is only being used for peaceful purposes so the West has no right to force Iran to stop its nuclear activities. Seeing that the P5+1 states clearly did not trust Iran with these nuclear capabilities, reaching a diplomatic solution was difficult. That is why both parties had to compromise in the end, and the result was allowing Iran to continue a limited nuclear enrichment project that could only be used for generating energy, while the $\mathrm{P} 5+1$ formed a committee that could conduct surprise visits to the Iranian nuclear facilities to ensure that Iran followed the Joint Comprehensive Plan. Oman's mediation role and its strong relationships with both parties ensured that the final result of these negotiations was a plan that retained Iranian dignity and enabled Iran to continue its peaceful nuclear projects while also putting any western worries to rest (Schmierer, 2015). Relations between Oman and Iran are not only political and diplomatic. In September 2013, both countries signed a memorandum of understanding on the topic of increasing military cooperation in many forms, one of which was conducting joint naval exercises in the strategic Strait of Hormuz (Iran Daily, 2015). According to Admiral Amir Hossein Azad, Commander of Iran's first Naval Zone, these naval exercises and joint drills were done to ensure the safety of all ships crossing the Strait of Hormuz, and to show that the Strait was well protected by both states. The exercises were conducted jointly to show cooperation and friendship between Oman and Iran, and their joint goal of ensuring the peace, stability and security of the region. Oman and Iran have also held Joint 
Military Friendship Committee meetings in order to discuss strengthening their military cooperation and the development of strategic relations between the two countries (MEE, 2014). This, paired with the joint drills Oman had with other GCC countries, shows that Oman has indeed attempted to achieve a nonaligned policy in dealings with all parties in the region. These military drills followed the visit of the Iranian president Hassan Rouhani to Oman in March 2014. Marc Valeri, an Omani specialist at Exeter University, expressed his opinion that this visit was a way "to thank Oman for its role" in facilitating the thawing of relations between Iran and the West and also to show "other Gulf countries that Muscat will continue good relations with Iran no matter what others think.» This shows Oman's independence in this matter, and that it will not blindly follow other states in boycotting Iran just because another strong player said so.

Oman's diplomatic relations with Iran are also evident in negotiations between Iran and UAE with regard to the three disputed islands in the Arab Gulf. The three islands: Abu Musa, Greater Tunbs and Lesser Tunbs are strategically located near the Strait of Hormuz, and have been a disputed territory since 1971, when the UK withdrew from the previously unclaimed islands and bequeathed the islands to both Iran and the Arab sheikhs on the Arabian side of the Gulf. The Shah of Iran seized control of the three islands and $U A E$, who had recently gained independence from the UK, was too fragile to demand any control over the islands. Even though the sheikhs of Sharjah formed an interim deal with Iran over Abu Musa in 1971, Iran has increased its military presence in the island and monopolised control over the three islands (Henderson, 2008). In 2014, UAE officials confirmed that there have been secret talks between Iranian and UAE officials in regards to the disputed territory, talks in which Oman was a mediator. The talks resulted in a deal which handed the UAE sovereignty over the Greater and Lesser Tunbs, but Abu Musa was treated differently and all specifics regarding it were still being discussed. Iran would maintain seabed rights around the three islands and would be granted a strategic point in Ras Musandam Mountain, a point that overlooks the entire Gulf. Oman in return, would get free gas and oil from Iran once a pipeline connecting the two was constructed (Writer, 2014).

Oman has also been active in helping other countries resolve their issues with Iran in regards to several cases of foreigners being imprisoned in Iran. The first example is Oman's assistance in releasing CanadianIranian university professor Homa Hoodfar, who was detained for four months in an Iranian prison. Oman did not publicize its efforts in this matter but it was clear that their assistance was effective seeing that the Canadian Prime Minister Justin Trudeau thanked Oman for its help in the case in a statement he made following the release of the professor $(\mathrm{Ha}$, 2016). Oman was also involved in the release of four American prisoners who were held in Iran on charges of export violations. The release was part of a prisoner swap between the US and Iran, mediated by Oman (Solomon \& Fitch, 2016).

But why would Oman make such a huge effort to reconcile its ties with Iran and Iran's ties with the Gulf and the West? One of main reasons is to avoid any military conflict between Iran and other key players within the region, thus stabilising the gulf region, an act that would also serve Omani internal and external security. Peace-making efforts would also improve Oman's prestige in the international arena proving that Oman is an active player in the region. Moreover, these diplomatic efforts would strengthen ties between Oman and other key players in the region such as the US and Iran. According to the Iranian Deputy Foreign Minister for Arab and African Affairs Hossein Amir-Abdollahian, Oman's diplomatic views are balanced, realistic and logical. He also added that continuing cooperation with Oman would lead to furthering the stability of the region.

It is clear that Oman aims to maintain a strategic relation with Iran as it is a key regional player in the Gulf and the Middle East. The Omani government also plans to maintain strong relations with both Saudi Arabia and Iran, two of the most powerful and influential actors in the region. By doing this, Oman adopts an impartial policy, which fosters its efforts to mediate between conflicting entities today or in the future. Oman's pragmatic approach of maintaining cooperation and dialogue with Iran leads to an understanding of Oman's belief that these relations are essential for stability of the region in both the short and long term. This belief in dialogue and cooperation is one of the main reasons that stopped Oman from participating in the GCC Union proposed in 2013, a union which planned direct confrontation with Iran, an approach that clashes with Oman's soft dialogue-based and non-intervention policies.

\section{Hormuz:}

The Strait of Hormuz is an internationally important strait between Oman and Iran. About 35\% to $40 \%$ of international oil exports pass through the Strait. About 20 to 30 oil vessels carrying about 18 million barrels of crude oil per day. About $85 \%$ of Japan's oil exports pass through Hormuz (Solomon \& Fitch, 2016). Furthermore, Hormuz is under Oman's sovereignty. According to international maritime law, each state has 
sovereignty over 12 miles from its shore which equals $22 \mathrm{KM}$. Beyond that are international waters. For that reason, Oman is the main state responsible for the strait. However, Oman and the entire international community consider Hormuz as an international strait due to its vitality in the world; therefore, its safety and security is considered an international responsibility. Oman proposed a technical project to empower its military forces to guard the Strait of Hormuz at a cost of 250 million US dollars paid over a duration of 10 years. This amount would be paid by Gulf countries who are financially capable and rely on the Strait for their oil exporting activities. Unfortunately, this project was stopped because Iraq, Kuwait, Bahrain and Saudi Arabia rejected it.

Iran has threatened, on more than one occasion, to close the strait when it was pressured by other states, mostly the United States of America. Oman considered, and still considers, such threats intimidation techniques to get Iran's point across. Iran relies on the Strait of Hormuz to export its oil, so closing the Strait will affect it negatively too. However, Oman still attempts resolve all issues between Oman and other states to ensure that these issues will not escalate into a conflict in the region.

Oman realizes the dangers of closing the Strait as any closure may create conflict and lead to disastrous consequences. Oman follows the international maritime law and keeps its responsibility of securing the transit of vessels even though any closure might help Omani oil prices. Oman recognises that peace and stability in the region are more important (Solomon \& Fitch, 2016).

\section{Economic Relations:}

Two of the most important relationships between Oman and Iran are economic and commercial relations. Economic relations between Oman and Iran are increasing and developing year after year, because of the wise diplomatic vision of the Omani government which has always insisted on maintaining a friendly relation based on cooperation and mutual benefit with its neighbours. Oman, which played the mediator role in Iranian issues, has started to gain economic benefits from its unique relations with Iran, which in return gained many benefits as well. The highest point of these mutual benefits and cooperation was reached after the reintegration of the Iranian economy into the global economy following the P5+1 nuclear deal which lifted the economic sanctions imposed on Iran. The current economic relationship between Oman and Iran is utilitarian reciprocal, meaning that both parties are beneficiaries. Iran is using Oman as a bridge linking its companies with other parts of the
Arab world, which helps Iran in the expansion of its exports of commodities and goods to new markets in Africa, Asia and the Arab world. On the other hand, Oman enjoys the largest proportion of Iranian investment in different sectors which contributes positively to the Omani economy especially under the current circumstances of falling oil prices.

The Iranian ambassador Ali Akbar Sibeveih said that "we will give priority to those friends who stood by us during the time of hardship. Definitely, the Sultanate of Oman and His Majesty Sultan Qaboos bin Said have a special and important place among Iran's loyal friends" ( Ilham, 2015). In addition, the Iranian Foreign Ministry spokesman Seyyed Abbas Araqchi said that "Economic cooperation and issues pertaining to the energy sector will be the main focus of ... talks and negotiations...," Omani minister of foreign affairs Yusuf bin Alawi said that "Iran - Oman trade projects will be operational soon". On another occasion, he added that "The two countries intend to strengthen bilateral relations and expand joint investment in the field of energy". This statement shows the good intention of both states and their efforts to enhance their bilateral trade and commercial relations.

Additionally, Iran invests a lot of capital in Oman due to the close geographical proximity between the two countries; Oman is the closest GCC state to Iran. Another reason is that the Omani investment arena isn't as competitive as that of UAE, the second closest GCC state to Iran. Bahrain and Saudi Arabia closed doors to Iranian investment due to political tension and the fear of Sunni and Shia clashes. Kuwait and Qatar are difficult to invest in as both states have many strong national trading families, who pressured their governments to halt or recede any foreign investments.

Economic and trade cooperation have taken different forms. The volume of economic projects has increased and investments have expanded. The most important sector that Oman is currently expanding is the logistic services sector, mainly focusing on sea ports. The Omani and Iranian governments aim to exploit their strategic maritime locations by improving the services provided for marine transportations. As a result, interactions between Chabahar an Iranian port and other Omani ports have expanded. In addition, Sohar, an Omani port, is now linked with the Iranian port Bandar Abbas by a shipping line between them (Times of Oman, 2015).

Many agreements were reached regarding this vital sector of logistic services, and a major agreement is the Salalah port agreement with Shahid Rajee Port and Chabahar Port. The deal aims to facilitate close cooperation between the two countries which will 
boost the shipping services. "With multiple main line services already providing a comprehensive and reliable global connectivity via Salalah, and the strong interest shown by all shipping lines in catering to the growing Iranian economy, this pioneering agreement will act as a facilitator and a platform for the three ports to work together to provide best in class logistics and supply chain solutions for multiple stakeholders," stated Ahmed Akaak, deputy CEO of the Port of Salalah who signed the agreement (Muscat Daily, 2016).

The Omani National Ferries Company (NFC) has recently launched a line between Khasab and Qeshm Island in Iran. This project is the company's first venture outside Oman, and is expected to open new venues for cultural, commercial and touristic relations. The Sultanate of Oman has also signed a memorandum of understanding with Iran in the field of exporting Iranian gas to the Sultanate starting from 2015 and continuing for 25 years exporting gas worth about \$ 60 billion USD (Times of Oman 1, 2015). According to the latest statistics from BP, Iran has the largest gas reserves in the world. In addition to that, the Omani stations produced 10.4 million tons of liquefied gas per year, but production did not exceed 8.8 million in the last five years and fell to 8.4 million in 2012, according to the latest annual report of Oman Liquid National Gas (LNG). The memorandum is useful for both sides (Times of Oman, 2016).

Al Duqm is a vital port in Oman which has recently attracted the attention of many investors, one of whom is Iranian multinational car maker Khodro which will establish an automobile plant in Southern Oman. The plan for the company was to become operational in 2017, and produce 20,000 units by 2018. The expected investment is approximately 200 million USD. The markets for the product will include Oman, Iran and other countries such as Ethiopia, Eritrea, Sudan and Yemen (Construction Week, 2015). "As Omani-Iranian trade grows, and ports such as Duqm offer Iran opportunities to develop new markets across the Indian Ocean, Oman's fellow GCC states will also have much to gain from the Sultanate's expanding infrastructure and its access to the Arabian Sea and the Indian Ocean," the Arabian Monitor said (Atanasova, 2016).

The annual bilateral trade between Oman and Iran recently grew by about $70 \%$. According to Mohammed Reza Nematazadaeh, Iran's Minister of Industry, Mines and Trade, investments in Oman are likely to reach $\$ 4$ billion within five years.

In the financial sector, the most popular bank and the largest lender by market value in the Sultanate of Oman is Bank Muscat. The bank has recently announced that it will open a representative office in Tehran after obtaining the approval of the Omani Central Bank. Following this step, Bank Muscat will be the first foreign financial firm to establish an official office in the Islamic Republic of Iran since the implementation of international sanctions. The Central Bank has also approved the operation of new money exchange companies such as Musandam Exchange within two years (Muscat Daily 2, 2016). Visits between the two nations have taken place in different times and places. The Omani Chamber of Commerce and Industry received a trade delegation from the Islamic Republic of Iran which consisted of representatives from 60 of Iran's largest companies, institutions and the private sector. These visits aimed to facilitate the founding of economic and business partnerships and to provide mutually beneficial investment opportunities for business in both countries. This was followed by Oman's efforts to facilitate visa issuance to Iranian investors. In addition, Oman has made it easier for Iranian boats to obtain port permits in order to facilitate and increase transit trade, another case where Oman seeks to improve the logistics sector (Times of Oman 3, 2015). In April 2015 The Omani Chamber of Commerce organized a trade delegation of more than 60 Omani business leaders representing different sectors and activities, and representatives of government bodies and companies to visit the Islamic Republic of Iran. The delegation provided information about the regulations and legislations governing investment in the Sultanate during this visit. The delegation learned about free zones in Iran, available for joint investment opportunities (Times of Oman 3, 2015).

The joint Omani Iranian Economic Committee plays an important role in enhancing economic relations between the two states. The agreement on trade in 2003, which aimed to eliminate non-tariff obstacles, the exchange investment agreement and Agreement on the Avoidance of Double Taxation were generated by this committee (Muscat Daily 4, 2016). Oman opened the Iranian Exhibition, which showcased the products of only one country, the Islamic Republic of Iran, which portrays Iran as a country full of a wide range of industries and products which are characterized by quality and abundance in production, especially with regard to handicrafts and traditional industries such as Persian rugs which are world-renowned. More than 70 Iranian companies participated in the exhibition to promote their products, as the exhibition aimed to expand the volume of bilateral trade exchange between the two countries. It also aimed at providing an opportunity for owners of small and medium enterprises in Iran to expand their business and make new business alliances, which would also benefit 
Omani enterprises (Times of Oman 5, 2015).

Cooperation between Oman and Iran is not limited to oil or gas sectors. Multiple agreements exist in energy, tourism, environment, finances, marine navigation and customs as well. A range of non-oil projects are either established or will be established soon. Iran is planning to open large factories of some of the major pharmaceuticals manufacturers for the production of medical drugs in Oman. Another plan is to build a nanotechnology plant in Oman. All of those projects will be extremely beneficial to Oman in its quest to increase the sources of income and become less dependent on the exportation of oil and gas.

Iran will establish a hospital in Oman which consists of 30 floors divided into three buildings. Omani nationals think very highly of Iranian medical services. "We receive many patients from Oman at the Iranian Hospital in Dubai, and many patients also visit Iran for treatment. Omanis have confidence in Iranian doctors and treatment and we also have great respect for them. So we decided to bring our services closer to Omanis" noted Dr. Ali Asgari, the hospital's medical director (Times of Oman 6, 2015).

It is clear that Oman and Iran are going forward to forge better economic relations, which will fuel the interests of both nations and will show its results in the very near future. These investments will also act as a way to increase stability in the region, seeing that Iran is less likely to cause conflicts in a region that it invested millions of US dollars in. These gains were not Oman's main goal in facilitating and encouraging peace in the region, but it is a gain that cannot be ignored.

\section{Conclusion:}

To conclude, the relations between Iran and Oman are built on mutual respect, cooperation and noninterference. On multiple occasions, Oman has played the part of a mediator between Iran and other states. It can be said that Oman is Iran's only friend in the region, and seeing that Iran is one of the strongest players in the Gulf, this is very important. These relations show the success of Omani foreign policy in looking for peaceful ways to resolve misunderstandings and conflicts, and in more than one occasion, these policies have impacted Oman in a positive way.

\section{Bibliography:}

Abu-zaid, Sarkese, «Iran And The Arab Orient: Confrontation or Co-Operation» 2010 Beirut, Lebanon center of civilization P81
Al-Rawas, Ali «Why Hormuz strait, International oil gate», Muscat, Oman, Oman Establishment for Press, Publication \& Advertising p134 - 136

Atanasova, S. Iran-Oman ties deepen, create downstream ops. Jul 3, 2016, Retrieved from http:// www.arabianoilandgas.com/article-15875-iranoman-ties-deepen-create-downstream-ops/

Bank Muscat opens Iran office. (2016). Global Banking News (GBN).

Bazoobandi. S (2015) "Iran's Economy and Energy: Back in Business" in Iran after the Deal: the Road Ahead. Milano: ISPI

BBC (2015, August 20). Timeline: Iran and UK relations. BBC NEWS. Retrieved from http://www.bbc.com/ news/uk-15949285

BBC, (2016, January 16). Iran nuclear deal: Key details. BBC NEWS. Retrieved from http://www.bbc.com/ news/world-middle-east-33521655

Bilateral trade between Oman and Iran hits $\$ 600 \mathrm{~m}$. Times of Oman.2014.

Construction Week, Iran Khodro plans vehicle assembly plant in Oman. (2015).

Ha. T.T. ( 2016, September 26). Canadian professor Homa Hoodfar arrives in Oman after release from Iran jail. The Globe and Mail. Retrieved from http:// www.theglobeandmail.com/news/national/iranreportedly-releases-canadian-prof-detained-sincejune/article32050382/

Henderson. S. (2008). The Persian Gulfis (Occupied Territory': The Three-Island Dispute. Policy Watch. 1402.

Ilham, M., Oman is Iran's trade priority, says ambassador, Times of Oman, July 15, 2015 Retrieved from

http://timesofoman.com/article/63851/Business/ Economy/Oman-is-Iranıs-trade-priority-saysambassador

IRAN DAILY, (2015, December 23). Iran, Oman launch naval exercises at Strait of Hormuz. Iran Daily. Retrieved from http://www.iran-daily.com/ News/133541.html? catid=3\&title=Iran--Omanlaunch-naval-exercises-at-Strait-of-Hormuz 
Iran, Oman stress development of bilateral economic ties. 2015 Iranian Students News Agency (ISNA.

Lefebvre, J. A. (2010). Omanss foreign policy in the twenty Abu-zaid, Sarkese, «Iran And The Arab Orient: Confrontation or Co-Operation» 2010 Beirut, Lebanon center of civilization P45

MEE, (2014, April 8). Iran and Oman hold joint naval exercises. Middle East Eye. Retrieved from http:// www.middleeasteye.net/news/iran-and-oman-holdjoint-naval-exercises-493167941

Muscat Daily 2, CBO CLEARS BANK MUSCATIS PLAN TO OPEN TEHRAN OFFICE, 2016

Muscat Daily 4, 2016, Oman-Iran joint economic panel to meet tomorrow.

Muscat Daily, 2016, SALALAH PORT SIGNS MOU WITH IRANIAN PORTS TO FACILITATE TRADE GROWTH, 2016, Muscat, Oman.

Schmierer, R.J. (2015). The Sultanate of Oman and the Iran nuclear deal. Middle East Policy. 22(4), 113-120. Doi: 10.1111/mepo.12162

Solomon. J. and Fitch. A. (2016, January 16). Iran Releases Americans in Prisoner Swap. The Wall Street Journal. Retrieved from http://www.wsj.com/articles/ iran-releases-four-unnamed-american-prisonersstate-tv-says-1452955793.

Times of Oman 1, Iran-Oman gas project reportedly hits a snag, 2015.Muscat, Oman.

Times of Oman 3, 2015, Omani delegation to visit Iran to explore new avenues for trade and other stories. Times of Oman

Times of Oman 3, 2015, Sixty Omani businessmen to explore Iranss market.

Times of Oman 5, 2015, Iranian Products Exhibition opens in Oman.

Times of Oman 6, 2015, Iran to set-up \$1.5b hospital complex in Oman by 2018.

Times of Oman, First Iranian ship operating under Iran-Oman agreement docks at Sohar, 2015, Muscat, Oman.

Times of Oman, Iran oil minister to visit Oman to finalize gas pipeline deal, 2016, Muscat, Oman.

Torbati. Yaganeh (2013, August 25). Oman's Qaboos on Tehran visit, U.S.-Iran mediation in focus. Reuters. Retrieved from http://www.reuters.com/article/usiran-oman-idUSBRE97006820130825

UN Security Council Resolution 1696/2016, Iran must halt all uranium enrichment activities or face sanctions, (31 July 2006)

Writer, Staff (2014, January 16). UAE, Iran strike deal over disputed islands. Arabian Business. Retrieved from

http://www.arabianbusiness.com/uae-iranstrike-deal-over-disputed-islands-report-534873. html\#.V_6TPuB942w 